\title{
Edilemma, a new genus of jumping spider from Tocantins, Brazil (Araneae, Salticidae)
}

\author{
Gustavo R. S. Ruiz \& Antonio D. Brescovit \\ ${ }^{1}$ Laboratório de Artrópodes, Instituto Butantan. Avenida Vital Brazil 1500, 05503-900 São Paulo, São Paulo, Brasil. \\ E-mail: gustavoruiz86@hotmail.com; adbresc@terra.com.br
}

\begin{abstract}
Edilemma gen. nov. is proposed to include the type species $E$. foraminifera sp. nov. from the Cerrado of the State of Tocantins, Northern Brazil.

KEY WORDS. Neotropical Region; systematics; taxonomy.
\end{abstract}

RESUMO. Edilemma, um novo gênero de aranha papa-mosca do Tocantins, Brasil (Araneae, Salticidae). Edilemma gen. nov. é proposto para incluir a espécie-tipo E. foraminifera sp. nov. do Cerrado do Estado do Tocantins, Brasil. PALAVRAS-CHAVE. Região Neotropical; sistemática; taxonomia.

In this paper we propose the new genus Edilemma to include the new species E. foraminifera, from the State of Tocantins, Northern Brazil. The genus seems to be related to Kalcerrytus Galiano, 1999, with which it shares a distal ventral projection on the femur of the male palp and a flattened embolus tip (see GALIANo 1999, figs 2-12, 14-15, 17, 20-37 and Ruiz $\&$ BRESCOVIT 2003, figs 1-2, 6-8, 10-11, 13-14, 16, 19, 21). Conversely, the dorsal color pattern is similar to species of the Freya decorata group (GALIANo 2001, fig. 1). Genital structures of $E$. foraminifera are unique within the family, which support the proposal of a new genus. It has a dorsal flap on the embolus of the male palp and a hood at the center of the female epigynal plate.

The material examined was collected in pitfall traps in an area of "Cerrado", a phytogeographic region, found exclusively in Brazil, with a poorly known biodiversity. It is characterized by very old and deep soils and by a regular and moderate dry season. Temperatures range from $22^{\circ} \mathrm{C}$ to $25^{\circ} \mathrm{C}$, reaching $40^{\circ} \mathrm{C}$ and $10^{\circ} \mathrm{C}$ in summer and winter, respectively (RizzINI 1997).

\section{MATERIAL AND METHODS}

The material examined is deposited in the Instituto Butantan (IBSP, A.D. Brescovit). The measurements are given in millimeters. The abbreviations used in the spinulation formulae are: (d) dorsal, (p) prolateral, (r) retrolateral, (v) ventral, (pr) proximal, (di) distal.

\section{Edilemma gen. nov.}

Type species: Edilemma foraminifera sp. nov.

Etymology. The generic name is an arbitrary combination of letters. The grammatical gender is feminine.

Diagnosis. Species of the genus Edilemma can be distinguished from the remaining salticid genera by the presence of a subapical dorsal flap on the embolus of the male palp (Fig. 2) and by the presence of a hood at the center of the female epigynal plate (Fig. 5).

Description. Small spiders (males 3.65-4.15 long, females 5.00 long), carapace subrectangular, wider at the middle (Fig. 1). Chelicera small, conical, parallel, with two teeth on promargin, one on retromargin and no other modifications on either sex. Endite rectangular, with no conspicuous projection. Labium subtriangular. Sternum oval. Male palp with a distal retroventral rounded projection and a small, acute retrolateral tibial apophysis; tegulum oval and embolus curved with a dorsal subapical flap and a flattened tip (Figs 2-4). Spinulation (variation in parentheses). Male: femur I d1-1-1, p2di, II d1-1-1, p2di, r1di, III d1-1-1, p0-1-2, r1di, IV d1-1-1, r1di; patella I, II p1, III, IV p1, r1; tibia I p1-1-1, v1r-1r-2, II p1-0-1, v1r-1r-2, III d1pr, p1-1-1, r1-11, v1p-0-2, IV d1pr, p1-1-1, r1-1-1, v0-1p-2; metatarsus I v2-2, II p1di, v2-2, III p1-0-2 (p2-0-2), r1-1-2, v2-0-2, IV p1-1-2, r1-1-2, v0-1p-2. Female: femur I d1-1-1, p1di, II d1-1-1, p2di, III d1-1-1, p2di, r1di, IV d1-1-1; patella I, II 0, III, IV p1, r1; tibia I v1r-2-2, II v1r-1r-2, III p1-1-1, r1-1-1, v0-1p-2, IV d1pr (d0), p1-1-1, r1-11, v0-1p-2; metatarsus I, II v2-2, III p1-0-2, r1-1-2 (r1-0-2), v2-02 , IV p1-1-2, r1-1-2, v0-1p-2. Abdomen oval. Female epigynum with a large semicircular atrium, inside of which there is a round structure bearing a median hood (Fig. 5). Internally with moderately long and coiled copulation ducts, small spermathecae and apical fertilization ducts (Fig. 6).

Distribution. Known only from State of Tocantins, Brazil.

\section{Edilemma foraminifera sp. nov.}

Figs $1-6$

Types. Male holotype from BraziL, Tocantins: Porto Nacional, 14-23.II.2003, I. Knysak \& R. Martins leg., deposited in IBSP 51804; one male and two female paratypes with the same data as holotype, deposited in IBSP 51805-51807. 

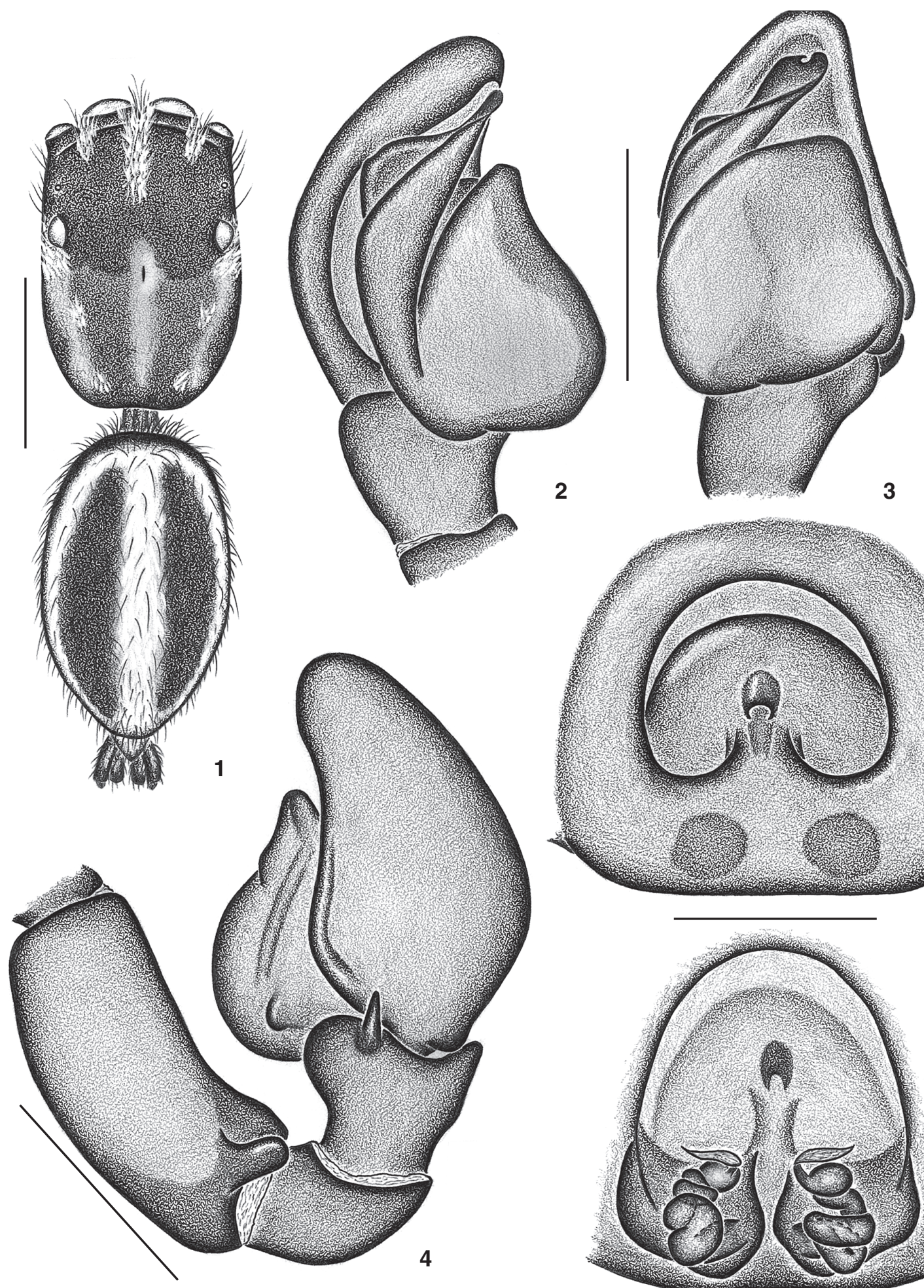

3

5

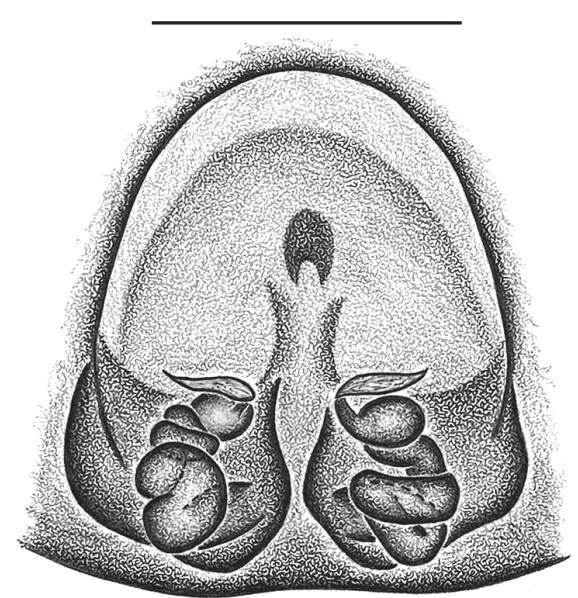

6

Figures 1-6. Edilemma foraminifera sp. nov.: (1) male holotype; (2) left male palp, prolateral view; (3) ventral view; (4) retrolateral view; (5) female, epigynum, ventral view; (6) dorsal view. Scale lines: (1) $1 \mathrm{~mm},(2-6) 0.25 \mathrm{~mm}$. 
Etymology. The specific name is composed by the Latin noun "foramen" and the verb "fero" and means "hole bearer". It refers to the small, deep hood at the center of the female epigynal plate.

Diagnosis. See generic diagnosis.

Description. Male (holotype, Fig. 1). Total length: 4.15 . Carapace reddish brown, 1.90 long, 1.30 wide, 0.87 high, with a pair of parallel variegated brown stripes extending from between the posterior lateral eyes to the posterior edge of the carapace; laterally variegated with dark brown and with dark brown borders. Cephalic region dark brown. Ocular quadrangle 0.90 long. Anterior eye row 1.20 wide and posterior 1.15 wide. Many sparse white scales on the carapace; a dense longitudinal median stripe of white scales on the cephalic region and a pair laterally. Clypeus with a median tuft of long white hairs projecting downward over the chelicerae. Chelicera reddish brown, with two teeth on promargin, one on retromargin. Endite light brown, variegated with dark brown retrolaterally. Labium light brown. Sternum dark brown. Palp dark brown, with a dorsal row of long white hairs on the femur, a small, acute retrolateral tibial apophysis and a flat ventral tibial projection; tegulum oval, with a proximal retrolateral projection and a curved embolus, which has a dorsal subapical flap and a flattened tip (Figs 2-4). Legs 4312. Coxae variegated with light and dark brown; trochanteres dark brown; femora I and II dark brown, with a pair of dorsal longitudinal light brown stripes; III and IV medially light brown, proximally and distally dark brown; patellae and tibiae I and II, and metatarsus I dark brown; metatarsus II medially brown, proximally and distally dark brown; patellae III and IV light brown; tibiae and metatarsi III and IV medially light brown, proximally and distally dark brown; tarsi light brown. Length of femur: I 0.95, II 0.85, III 1.10, IV 1.02; patella + tibia: I 1.27, II 1.02, III 1.10, IV 1.10; metatarsus + tarsus: I 0.87, II 0.72, III 1.00, IV 1.12. Abdomen cream, with a pair of dorsal longitudinal dark brown stripes; a median longitudinal stripe of white hairs between the dark stripes; laterally covered with white hairs, anteriorly dark brown (Fig. 1); ventrally cream, slightly variegated. Spinnerets dark brown.

Female (paratype, IBSP 51805). Total length: 5.00. Carapace as in the male, 2.02 long, 1.40 wide, 0.90 high, with less sparse white hairs and none on cephalic region and clypeus. Ocular quadrangle 1.00 long. Anterior eye row 1.30 wide and posterior 1.27 wide. Chelicera as in the male. Endite, labium and sternum yellow. Palp yellow, with small dorsal dark brown spots on the patella and tibia. Legs 4321, yellow; femora, tibiae and metatarsi proximally and distally dark brown; patellae I and II distally dark brown. Length of femur: I 1.00, II 0.92, III 1.20, IV 1.15; patella + tibia: I 0.72, II 1.05, III 1.12, IV 1.22; metatarsus + tarsus: I 0.77, II 0.75, III 1.05, IV 1.22. Abdomen cream, with the same coloration pattern as in the male, but less conspicuous, except for the dorsal longitudinal median light stripe, which in the female forms five spots (not perfect chevrons) on the posterior half. Epigynum with a semicircular atrium, inside of which there is a round structure bearing a median deep hood (Fig. 5). Internally with moderately long and coiled copulation ducts, small spermathecae and apical fertilization ducts (Fig. 6). Spinnerets cream, laterally dark brown on the outer side.

Variation. Seven males: total length: 3.65-4.15; carapace length: 1.80-1.95. Three females: carapace length: 2.02-2.15.

Additional material examined. Brazil, Tocantins: Porto Nacional, five males and one female, 14-23-II.2003, I. Knysak \& R. Martins leg. (IBSP 51808-51813).

Distribution. Known only from the State of Tocantins, Brazil.

\section{ACKNOWLEDGMENTS}

We wish to thank Conselho Nacional de Desenvolvimento Científico e Tecnológico (CNPq) and Fundação de Amparo à Pesquisa do Estado de São Paulo (FAPESP no. 99/ 05446-8) for financial support. We also thank G.B. Edwards, Cristina A. Rheims, Arno A. Lise and Ricardo Ott for helpful suggestions on the manuscript. This study is part of the BIOTA/ FAPESP - the Biodiversity Virtual Institute Program (www. biotasp.org.br).

\section{REFERENCES}

Galiano, M.E. 1999. Descripción de Kalcerrytus, nuevo género (Araneae, Salticidae). Physis (C), Buenos Aires, 57 (132-133): 53-71.

Galiano, M.E. 2001. Revisión de las especies de Freya del grupo decorata (Araneae, Salticidae). The Journal of Arachnology, Chicago, 29: 21-41.

RizzinI, C.T. 1997. Tratado de fitogeografia do Brasil. Rio de Janeiro, Âmbito Cultural Edições, $2^{a}$ ed., 747p.

Ruiz, G.R.S. \& A.D. BRESCOVIT. 2003. Description of six new species of Kalcerrytus Galiano from the Brazilian Amazon (Araneae: Salticidae). Revista Ibérica Aracnología, Zaragoza, 8: 73-79.

Received in 24.VI.2005; accepted in 11.IV.2006. 